J urral PenddkanBałesacknSastra V dume12, Nomr 2, Oktdber 2012

\title{
ADVERBIA STATIF DALAM BAHASA SUNDA: KAJIAN STRUKT UR DAN SEMANTIK
}

\author{
Yayat Sudaryat \\ FPBS Universitas Pendidikan Indonesia \\ Korespondensi: Jl. Dr. Setiabudhi No 229 Bandung 40154 \\ e-mail: kisduaryat_sunda@yahoo.com
}

\begin{abstract}
Abstrak
Adverbia Statif dalam Bahasa Sunda: Kajian Struktur dan Semantik. Kajian ini bertujuan mendeskripsikan adverbia statif dalam bahasa Sunda yang dikaji dari segi struktur dan semantik. D eskripsinya mencakup batasan dan karakteristik, fungsi, keterikatan, jumlah unsur, distribusi, makna, dan bentuknya. Dalam kajian ini digunakan metode deskriptif. Sumber data kajian ini berupa ragam bahasa Sunda lisan dan tulis. Untuk mengumpulkan data digunakan teknik teks, instuisi atau intropeksi, dan teknik elisitasi. Untuk mengolah data digunakan metode distribusional dengan analisis unsur langsung sebagai teknik dasar, yang diikuti teknik permutasi, subsitusi, ekspansi, dan teknik interupsi sebagai teknik lanjutan. Kajian ini menyimpulkan bahwa (a) adverbia statif merupakan adverbia yang secara khusus dan kolokatif menerangkan adjektiva; (b) adverbia statif berfungsi sebagai pewatas belakang adjektiva; (c) adverbia statif dengan adjektiva memiliki keterikatan yang sangat erat dan berkolokatif; (d) jumlah unsur adverbia statif dan adjektiva bersifat saling melengkapi; (e) posisi adverbia statif selalu di belakang adjektiva; (f) adverbia statif memiliki makna inhern 'sifat kesangatan (kualitas elatif )' yang dapat di dahului kata mani 'sangat'; dan ( $g$ ) adverbia statif pada umumnya berbentuk kata tunggal (71,42\%).
\end{abstract}

Kata kunci: adverbia statif, adjektiva, struktur, semantik, pewatas

\begin{abstract}
The Study of Structure and Semantics of Stative Adverbs in Sundanese Language. This study aims to describe stative adverbs in Sundanese language studied in terms of structure and semantics. D escriptions include definition and characteristic, function, relationship, number of elements, distribution, meaning, and form. This study used a descriptive method. Data source for this study were in the forms of spoken and written language varieties. Tecniques used to collect data are text, intuition or introspection, and elicitation tecniques. To process the data, the study used distributional methods with direct factorial analysis as the basic tecnique, followed by permutation, substitution, expansion, and technical interruptions tecnique, follow-up techniques. The study concludes that (a) stative adverbs are adverb that explain adjectives speciically and collocatively; (b) stative adverbs serves as adjective limiters; (c) stative adverbs with adjectives are bound very tightly and collocated; $(\mathrm{d})$ the number of elements stative adverbs and adjectives are complementary; (e) the position of stative adverbs ia always in the back of the adjectives; (f) stative adverbs have an inherent meaning of 'excessive nature (elative quality) 'which may be preceded by the word mani 'very', and (g) stative adverbs are generally inthe form of a single word $(71,42 \%)$
\end{abstract}

Keywords: stative adverbs, adjective, structure, semantics, limiter

p-ISSN 1412-0712 | e-ISSN 2527-8312 